\title{
Abundance and diversity of edaphic mites (Arachnida, Acari) under different forest management systems in Indonesia
}

\author{
MUHAMMAD IHSAN", RETNO DYAH PUSPITARINI"v, AMINUDIN AFANDHI, ITO FERNANDO \\ Department of Plant Pests and Diseases, Faculty of Agriculture, Universitas Brawijaya. J1. Veteran, Malang 65145, East Java, Indonesia. \\ Tel.: +62-341-575843, `email: muhammadihsan649@yahoo.com, ^^email: retnodyah@ub.ac.id. \\ Manuscript received: 2 July 2021. Revision accepted: 13 August 2021.
}

\begin{abstract}
Ihsan M, Puspitarini RD, Afandhi A, Fernando I. 2021. Abundance and diversity of edaphic mites (Arachnida, Acari) under different forest management systems in Indonesia. Biodiversitas 22: 3685-3692. Edaphic mites play crucial roles in maintaining ecosystem services that are essential to human needs. However, the conversion of natural habitats followed by agricultural intensification may adversely affect edaphic mites. The objective of this study was to investigate the influence of different management systems on edaphic mite abundance, richness, and diversity in tropical rain forests in Indonesia. There were five forest management systems, which were as follows: secondary forest, production forest (pine monoculture), and three agroforestry systems (pine + coffee, mahogany + coffee, and mahogany + new cocoyam). We established a transect containing five research plots for each forest management system. Litter and soil from each plot were collected from December to March 2021. Temperature, relative humidity, and $\mathrm{pH}$ of litter and soil, as well as litter thickness, were measured. We found that edaphic mite abundance, richness, and diversity in the secondary forest were similar to managed forests. However, the aforementioned variables were significantly higher in "pine" systems than in "mahogany" systems. Our analysis evidenced positive correlations between litter thickness and edaphic mite abundance, richness, and diversity. Our findings may assist in selecting the appropriate forest management systems to rationalize the conversion of secondary forests to production forests and agroforestry.
\end{abstract}

Keywords: Agroforestry, ecosystem services, production forest, richness, secondary forest, tropical rain forests

\section{INTRODUCTION}

The Acari is one of the most ubiquitous and speciose arachnid taxa, which includes ticks and mites. Unlike ticks, which are predominantly parasites on other animals, mites have various lifestyles (Krantz and Walter 2009). Some mite species are phytophagous and often cause economic damage in agricultural sectors (Vacante 2016; Puspitarini 2021a, b). However, the majority are free-living species that play vital roles in maintaining ecosystem health and function. It is widely accepted that edaphic (litter- and soildwelling) mites contribute to the continuity of environmental services, especially supporting and regulating services. Most edaphic mites are detritivores that partake in soil formation and minerals recycling by fragmenting litter and decomposing organic matter (Seastedt 1984; Wickings and Grandy 2011; de Groot et al. 2016). The rest are usually predators that may provide pest control services (Navarro-Campos et al. 2012; Park et al. 2021; Rueda-Ramírex et al. 2021). Additionally, many edaphic mites, such as oribatids, are used as bioindicators and model organisms in ecotoxicology studies (BehanPelletier 1999; Huguier et al. 2015; Ardestani et al. 2020). Therefore, a myriad of research was conducted to monitor edaphic mites' abundance and diversity (Dirilgen et al. 2016; Acharya and Datta 2019; Zaitsev et al. 2020).

Significant reduction in secondary forests caused by deforestation and their conversion into arable lands is a serious issue in most tropical countries (N'Dri et al. 2017).
This problem coupled with agricultural intensification can adversely affect the soil fauna communities (Mori et al. 2015). For example, many studies had observed reductions in edaphic mite abundance and diversity due to an excessive application of agrochemicals and intensive tillage (Minor and Cianciolo 2007; Murvanidze et al. 2019). Furthermore, the agricultural intensification may also eliminate key species and alter trophic interactions (Cao et al. 2011). However, to fulfill human needs, the conversion of secondary forests is inevitable. With this respect, converting secondary forests to production forests and agroforestry could serve as an alternative solution. The term production forest refers to a forest dominated by certain tree species that are intentionally planted, while agroforestry is a mixture of trees and perennial shrubs or annual crops. In addition to providing harvestable goods, these forest management systems could preserve soil biodiversity and may have resilience comparable to a secondary or even a primary forest (N'Dri et al. 2017).

The effects of different forest management systems on edaphic mites have been elucidated. The edaphic mite abundance and species richness vary in relation to the dominant tree species. According to Badejo and Tian (1999), planting Leucaena leucocephala (Lam.) de Wit enhanced the density, diversity, and complexity of edaphic mite communities than the other tree species used in their experiment. This variation can be attributed to the litter quality of each plant species (Urbanowski et al. 2021). A high-quality litter provides a more suitable habitat and 
condition for edaphic mites. The litter quality is measured in terms of its nutrient content and decomposition rate (Horodecki and Jagodziński 2017). Moreover, litter may indirectly affect edaphic mite populations by changing soil properties and microorganisms (Gergócs et al. 2015; Urbanowski et al. 2018).

In Indonesia, only a few studies had been conducted to evaluate edaphic mite abundance and diversity (Lisafitri et al. 2015; Sulistyorini et al. 2018; Bria et al. 2019). To date, the edaphic mites are little studied also in other parts of the globe. This present study aims to investigate the abundance, richness, and diversity of edaphic mites in five different tropical forest management systems. Our results may assist in selecting the appropriate forest management systems to rationalize the conversion of secondary forests to production forest and agroforestry when supported by ecologically sound reasons.

\section{MATERIALS AND METHODS}

\section{Study area}

The study was conducted in the "UB Forest" situated in Karangploso, Malang, Indonesia (7०53'35' S; 112 53 '41" E). This tropical rain forest, which is located on the south side of Mount Arjuna, is designated as a protected area by the Indonesian Ministry of Forestry. The total area of UB Forest is $13,572.06 \mathrm{~km}^{2}$, while the area used for production forests and agroforestry is $5,14 \mathrm{ha}^{2}$. Based on data maintained by the Meteorological, Climatological, and Geophysical Agency of Malang, the mean annual rainfall and temperature in UB forest (2019 to 2020) were about
$5.52 \mathrm{~mm}$ and $24.38^{\circ} \mathrm{C}$, while the average rainfall and temperature during the study (from the beginning of December 2020 to March 2021) were approximately 12.34 $\mathrm{mm}$ and $23.93^{\circ} \mathrm{C}$, respectively. Pine (Pinus merkusii Jungh. $\&$ de Vriese), mahogany (Swietenia mahagoni (L.) Jacq.), coffee (Coffea arabica L.), and new cocoyam (Xanthosoma sagittifolium (L.) Schott) are the most dominant cultivated plants. Farmers suggested that the age of pine stands is around 30 to 35 years, while the mahogany stands are about 35 to 40 years old. The coffee plants were planted about 8 to 10 years before this study, while new cocoyam plants are planted twice a year.

\section{Sampling design}

Five different forest management systems were determined during the preliminary surveys. One of the systems is a secondary forest, the other is a production forest, while the rest are considered agroforestry. The forest management systems were then set as follows: secondary forest; production forest (pine monoculture); and three agroforestry systems (pine + coffee, mahogany + coffee, and mahogany + new cocoyam). After that, a transect containing five research plots for each management system was selected by purposive sampling (Figure 1). Each plot was $20 \times 20 \mathrm{~m}$, and the distance between two consecutive plots was $50 \mathrm{~m}$. The criteria specified in the selection of the plots were that they are not close to a cliff and are easily accessible. All the selected plots are also not disturbed much by human activities. Agroforestry plots are not subjected to any agricultural practice except pine-tapping and harvesting coffee berry and new cocoyam corm, while logging is rare.
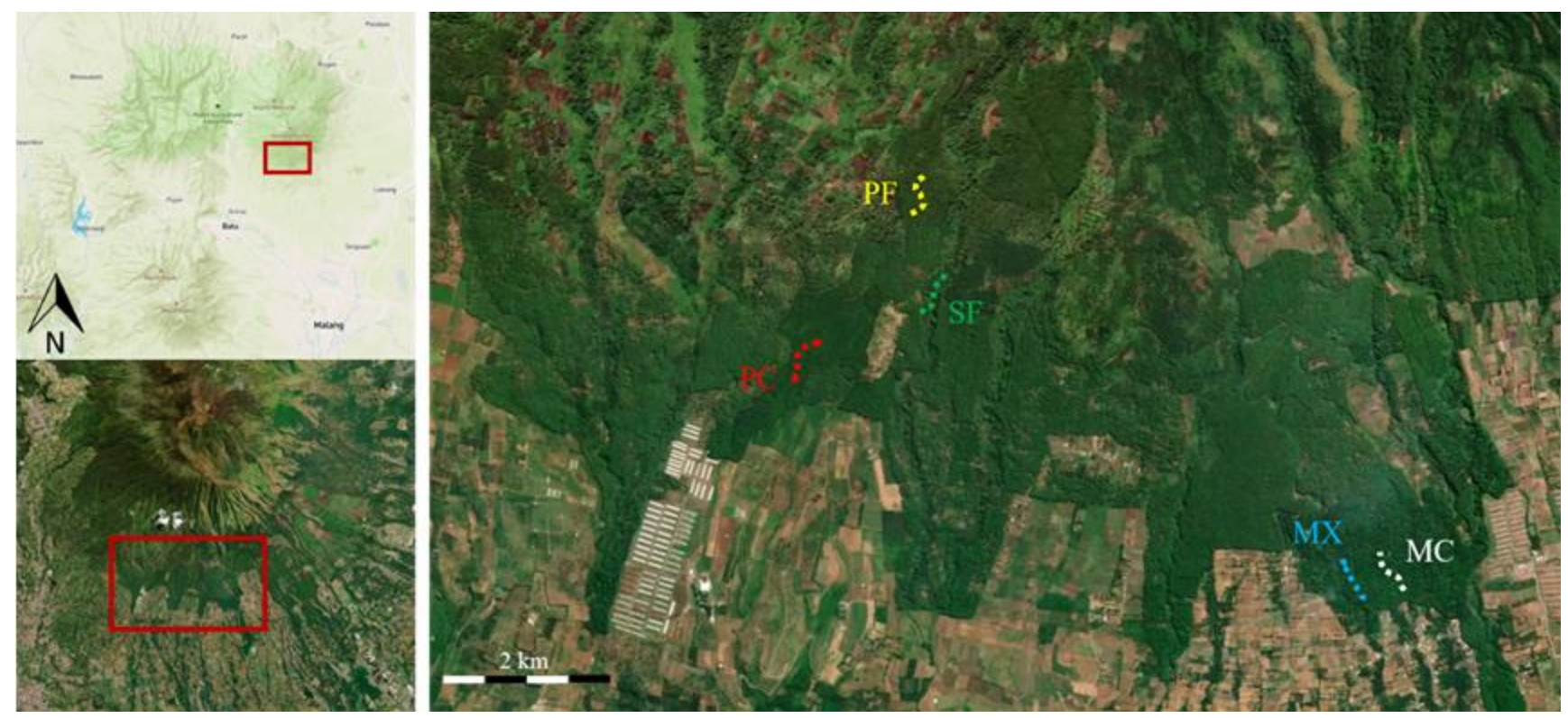

Figure 1. Map of the study area showing transects of the five forest management systems, each point along the transect represents the sampling plot. SF is secondary forest; PF is monoculture pine system; PC is pine + coffee system; MC is mahogany + coffee system; and MX is mahogany + new cocoyam system 
In each plot, ten sampling units were determined using a diagonal pattern. To characterize environmental conditions, physical properties of litter (thickness, temperature, relative humidity, and $\mathrm{pH}$ ) and soil (temperature, relative humidity, and $\mathrm{pH}$ ) were measured (Table 1). Measurements in each plot were carried out in the sampling unit located in the center. Measurements were conducted at two-week intervals from December 2020 to March 2021. In total, there were eight measurements during the study. However, the measurement of $\mathrm{pH}$ of litter and soil was conducted only once at the beginning of the study. Data measured in each plot was regarded as an independent replicate.

The tip of a calibrated thermohygrometer (HTC) was inserted into soil up to $20 \mathrm{~cm}$ in depth or middle of litter layers and left for one minute to measure soil and litter temperature and relative humidity. A $10 \mathrm{~g}$ of soil (taken from $20 \mathrm{~cm}$ depth) and $10 \mathrm{~g}$ of partially decomposed litter were used to measure soil and litter $\mathrm{pH}$. The soil and litter were then put into a vial, mixed with $10 \mathrm{ml}$ of distilled water, and agitated for 60 minutes using an orbital shaker (Protech $\AA$ ) at $220 \mathrm{rpm}$. After that, the $\mathrm{pH}$ of the solution was measured using a calibrated $\mathrm{pH}$ meter (Thermo Scientific $\left.{ }^{\mathrm{TM}}\right)$.

\section{Collection of litter and soil samples}

Litter and soil samples were collected from December to March 2021 (eight times in total). The collections of litter and soil samples were carried out around 06.00 to 10.00 a.m. In each sampling unit, $1 \mathrm{~kg}$ of soil was taken from the topsoil layer $(0-20 \mathrm{~cm}$ depth), while the amount of litter taken was $0.5 \mathrm{~kg}$. The litter and soil samples from the ten sampling units were composited prior to subsampling. After that, $1 \mathrm{~kg}$ of litter and soil from the composite samples were taken and placed in a plastic bag. Subsample from each research plot was regarded as an independent replicate.

\section{Extraction and mite identification}

Edaphic mites were extracted from the collected litter and soil using modified Berlese-Tullgren apparatus for two days (Murvanidze et al. 2019). Extracted mites were stored in alcohol-glycerol-lactic acid solution (Zhang 2003). Specimens were mounted semi-permanently using $85 \%$ lactic acid for three days to ensure maximum transparency of specimens (Urbanowski et al. 2021) or permanently using Hoyer's medium (N'Dri et al. 2017). Extracted mites were counted and identified to the family level using the keys of Balogh and Balogh (1992), Evans (1992), and Krantz and Walter (2009). Extracted mites were grouped into two guilds based on their feeding habits, which are predaceous and detritivorous mites. The feeding habits of the mites were determined according to Luxton (1972) and Krantz and Walter (2009). In general, predaceous mites have relatively long legs and do not have the beetle-like appearance of detritivorous mites.

\section{Statistical analysis}

Edaphic mite abundance was expressed as the mean number of individuals, whereas the edaphic mite richness was expressed as the mean number of families found. All data were initially transformed using the $\log (x+1)$ formula to meet the assumption of normality and variance homogeneity based on the Shapiro-Wilk and Levene test, respectively. However, means were reported as the backtransformed means. Analysis of variance (ANOVA) followed by Tukey's test was then used to compare the edaphic mite abundance and richness among different forest management systems. Diversity analysis were used to assess differences in edaphic mite community characteristics. The Shannon-Wiener diversity $\left(H^{\prime}\right)$, Pielou evenness $(E)$, and Simpson dominance index $(D)$ were calculated from the non-transformed data. The calculated indices values were subjected to ANOVA and Tukey's test. Pearson's correlation was used in order to elucidate the relationship between environment physical properties and the abundance, richness, and diversity of the edaphic mites. All statistical analyses were conducted at a significance level of $P<0.05$. All analyses were performed using $\mathrm{R}$ statistics (R Core Team 2020), utilizing the vegan package for community characteristics analysis (Oksanen et al. 2020).

Table 1. Means \pm SD of the measured environment physical properties describing the actual conditions of the five forest management systems (data were taken from five different plots for each system)

\begin{tabular}{lccccc}
\hline \multirow{2}{*}{ Physical properties } & \multicolumn{3}{c}{ Forest management systems } \\
\cline { 2 - 6 } & SF & PF & PC & MC & MX \\
\hline Litter thickness $(\mathrm{cm})$ & $2.48 \pm 1.08$ & $3.32 \pm 0.74$ & $3.34 \pm 0.64$ & $2.42 \pm 0.93$ & $2.25 \pm 1.01$ \\
Litter temperature $\left({ }^{\circ} \mathrm{C}\right)$ & $26.73 \pm 1.93$ & $26.67 \pm 3.46$ & $27.08 \pm 4.12$ & $25.54 \pm 2.26$ & $25.97 \pm 2.51$ \\
Litter relative humidity $(\%)$ & $71.02 \pm 6.53$ & $72.22 \pm 10.80$ & $71.15 \pm 11.92$ & $80.72 \pm 9.22$ & $77.07 \pm 10.13$ \\
Litter pH & $7.24 \pm 0.40$ & $6.54 \pm 0.11$ & $6.68 \pm 0.35$ & $7.10 \pm 0.30$ & $6.70 \pm 0.07$ \\
Soil temperature $\left({ }^{\circ} \mathrm{C}\right)$ & $22.38 \pm 1.31$ & $22.26 \pm 1.12$ & $22.13 \pm 1.39$ & $21.82 \pm 0.64$ & $21.55 \pm 1.05$ \\
Soil relative humidity $(\%)$ & $79.60 \pm 8.38$ & $81.52 \pm 11.43$ & $78.67 \pm 10.85$ & $86.20 \pm 10.73$ & $83.05 \pm 11.33$ \\
Soil pH & $6.18 \pm 0.13$ & $6.32 \pm 0.10$ & $6.26 \pm 0.15$ & $6.88 \pm 0.32$ & $6.78 \pm 0.33$ \\
\hline
\end{tabular}

Note: SF is secondary forest; PF is monoculture pine system; PC is pine + coffee system; MC is mahogany + coffee system; and MX is mahogany + new cocoyam system 


\section{RESULTS AND DISCUSSION}

\section{Abundance and richness of edaphic mites in different forest management systems}

The mean abundance of total edaphic mites changed significantly across the forest management systems. It was higher in pine monoculture $(174.10 \pm 113.90)$ and pine + coffee $(191.40 \pm 141.90)$ system, while it was lower in mahogany + coffee $(42.25 \pm 35.92)$ and mahogany + new cocoyam $(33.25 \pm 26.40)$ system. However, the total edaphic mite density in the secondary forest $(87.38 \pm$ 69.99) was not statistically different from the other managed forests. The same result was also observed when comparing the density of litter-dwelling mites. The density of litter-dwelling mites in pine monoculture (149.30 \pm $108.80)$ and pine + coffee $\left(156.00 \pm \pm^{`} 142.20\right)$ system was higher than the density recorded in mahogany + coffee $(28.13 \pm 29.40)$ and mahogany + new cocoyam $(22.63 \pm$ 21.21) system. In this investigation, the soil-dwelling mite density was not significantly different under the five forest management systems (Figure 2).

A total of 1 suborder, 1 superfamily, and 8 families of Oribatida, as well as 1 family of Prostigmata, and 1 family of Mesostigmata were identified (Figure 3). Members of trombidiid (Prostigmata) and laelapid (Mesostigmata) are predaceous mites, while all oribatids are detritivores. In general, a higher number of individuals of each taxonomic group was found in pine monoculture and pine + coffee system, for example in Laelapidae, Eremaeidae, Galumniidae, Lohmanniidae, Crotonioidea, and Brachypylina. The edaphic mite richness was significantly higher in pine monoculture $(8.12 \pm 1.64)$ and pine + coffee $(8.37 \pm 1.92)$ system than in mahogany + new cocoyam $(4.62 \pm 2.72)$ system, but it was similar to the richness in secondary forest $(6.12 \pm 1.64)$ and mahogany + coffee $(5.37 \pm 1.68)$ system. The densities of predaceous and detritivorous mites were also higher in pine monoculture $(61.88 \pm 34.24$ and $112.30 \pm 87.47)$ and pine + coffee system $(48.38 \pm 24.32$ and $143.30 \pm 134.30)$ than densities recorded in mahogany + coffee $(15.50 \pm 6.56$ and $26.75 \pm$ $34.73)$ and mahogany + new cocoyam $(8.87 \pm 7.27$ and $24.38 \pm 25.98$ ) system (Table 2 ).

\section{Community characteristics of edaphic mites}

From the analysis, the diversity of total and litterdwelling mites tended to be higher in pine monoculture $(1.52 \pm 0.21$ and $1.46 \pm 0.19)$ and pine + coffee $(1.54 \pm$ 0.17 and $1.48 \pm 0.18$ ) system, whereas the lower diversity of total and litter-dwelling mites was found in mahogany + coffee $(1.09 \pm 0.23$ and $0.91 \pm 0.28)$ and mahogany + new cocoyam $(1.07 \pm 0.52$ and $0.87 \pm 0.47)$ system. The evenness of total and litter-dwelling mites was higher in pine monoculture $(0.53 \pm 0.07$ and $0.51 \pm 0.06)$ and pine + coffee $(0.54 \pm 0.06$ and $0.52 \pm 0.06)$ system than in mahogany + coffee $(0.38 \pm 0.08$ and $0.32 \pm 0.09)$ and mahogany + new cocoyam $(0.37 \pm 0.18$ and $0.30 \pm 0.16)$ system. However, the ANOVA revealed that the diversity and evenness indices of soil-dwelling mites among the five forest management systems were not significantly different. With regard to the dominance index, the calculated values were not statistically different among the five forest management systems (Table 3 ).

\section{Relationships between environment physical properties and the abundance, richness, and diversity of edaphic mites}

The correlation analysis evidenced significant positive relationships between litter thickness and the abundance, richness, and diversity of edaphic mites (Table 4). The other litter and soil properties had no correlation with the edaphic mite abundance, richness, and diversity.

\section{Discussion}

Soil fauna, particularly edaphic mites, are primarily $K$ selected organisms characterized by their slow development, low fecundity, and poor dispersal capability (Behan-Pelletier 1999; Minor and Cianciolo 2007; Gao et al. 2014). Therefore, they are sensitive and vulnerable to exogenous disturbances. Consequently, edaphic mites have been regarded as suitable bioindicators to assess the effects of habitat conversion and land management on soil biodiversity (Khabir et al. 2015; Meehan et al. 2019; Amani et al. 2020). In this study, the abundance and richness of edaphic mites in the natural habitat (secondary forest) were not different from the other management systems, possibly due to the minimum disturbance in the evaluated research plots. It indicates that conversion of secondary forests to production forests and agroforestry may still preserve edaphic mite communities, as long as management systems with low inputs and minimum tillage are used. Our findings agreed with previous studies that found that edaphic mite abundance and richness in artificial forests were equal or could be higher than in natural forests (Bedano et al. 2006; N'Dri et al. 2017). Nevertheless, we found that higher density and richness of edaphic mites, especially litter-dwelling mites, were recorded in forest management systems with pine as the dominant tree species. Similarly, Maribie et al. (2011) reported that edaphic mite abundance and richness in the pine monoculture system were higher than in a natural forest and other managed forests evaluated in their study.

The collected edaphic mites consisted of three major taxa, namely Prostigmata, Mesostigmata, and Oribatida. In this investigation, oribatids were more abundant than prostigmatid and mesostigmatid mites regardless of the forest management systems. Oribatids have been known as the most dominant microarthropods in most forest floors and soils (González and Seastedt 2000; Gergócs and Hufnagel 2011). Dirilgen et al. (2016) suggested that a higher abundance of oribatids in forest habitats is due to the differences in feeding strategies among edaphic mite taxa. Oribatids mainly feed on detritus, fungi, and bacteria, which are omnipresent in forests (Smrž 2010). On the other hand, other taxa such as Mesostigmata, are pre-dominantly predaceous (Klarner et al. 2013), hence their numbers fluctuate depending on the prey availability. In this study, the number of individuals of laelapid, eremaeid, galumnid, lohmanniid, crotonioid, and brachypylin was higher in pine monoculture and pine + coffee management systems, so did the abundance of total predaceous and detritivorous mites. 
We found that the diversity and evenness of edaphic mites in the secondary forest were similar to the managed forests. Erdmann et al. (2012) proposed that different forest management systems may still harbor similar niches favorable for edaphic mites. Therefore, it is evident that under similar habitat types, the community structure and diversity of edaphic mites might not differ remarkably (Sylvain and Buddle 2010). Nonetheless, we recorded higher edaphic mite diversity and evenness in pine monoculture and pine + coffee management systems than in mahogany + coffee and mahogany + new cocoyam systems. Previous studies also reported that the edaphic mite abundance, richness, and diversity were high in pine forests (Maribie et al. 2011; Erdmann et al. 2012; Gergócs et al. 2015).

\section{Total mites}

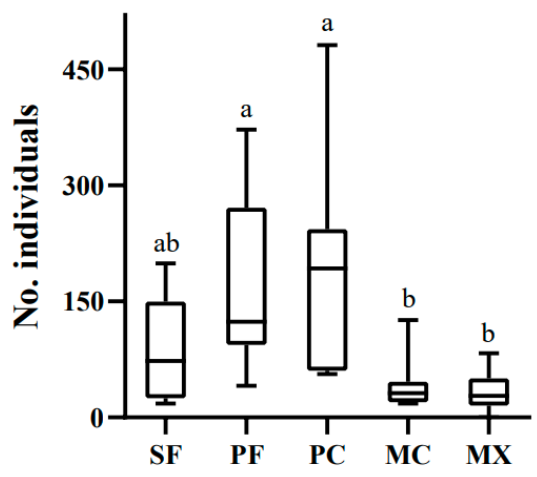

Litter-dwelling mites

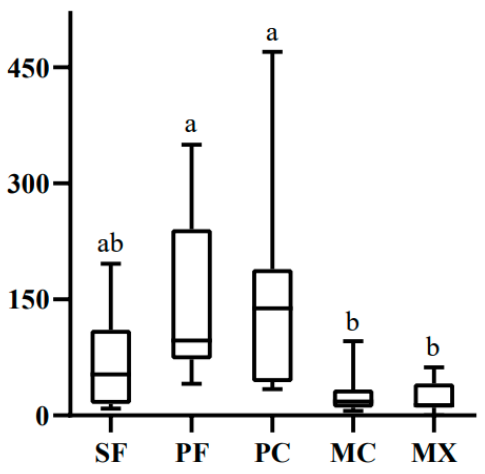

Soil-dwelling mites

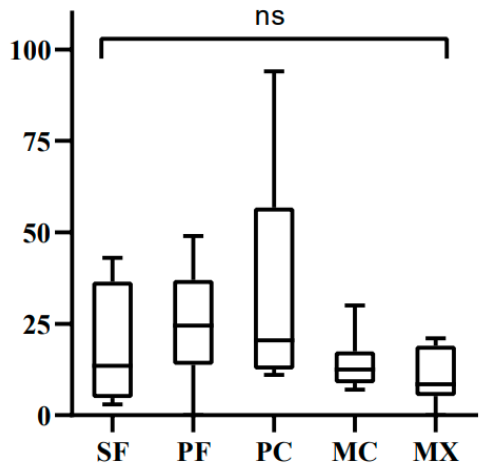

Forest management system

Figure 2. Effect of different forest management systems on the abundance of edaphic mites: total mites $\left(F_{4,35}=6.82 ; P<0.001\right)$; litterdwelling mites $\left(F_{4,35}=7.54 ; P<0.001\right)$; and soil-dwelling mites $\left(F_{4,35}=1.72 ; P=0.166\right)$. SF is secondary forest; $\mathrm{PF}$ is monoculture pine plantation; $\mathrm{PC}$ is pine + coffee plantation; $\mathrm{MC}$ is mahogany + coffee plantation; and $\mathrm{MX}$ is mahogany + new cocoyam plantation. Different letters denote significant differences, while ns denotes nonsignificant differences at $P<0.05$ according to Tukey's test

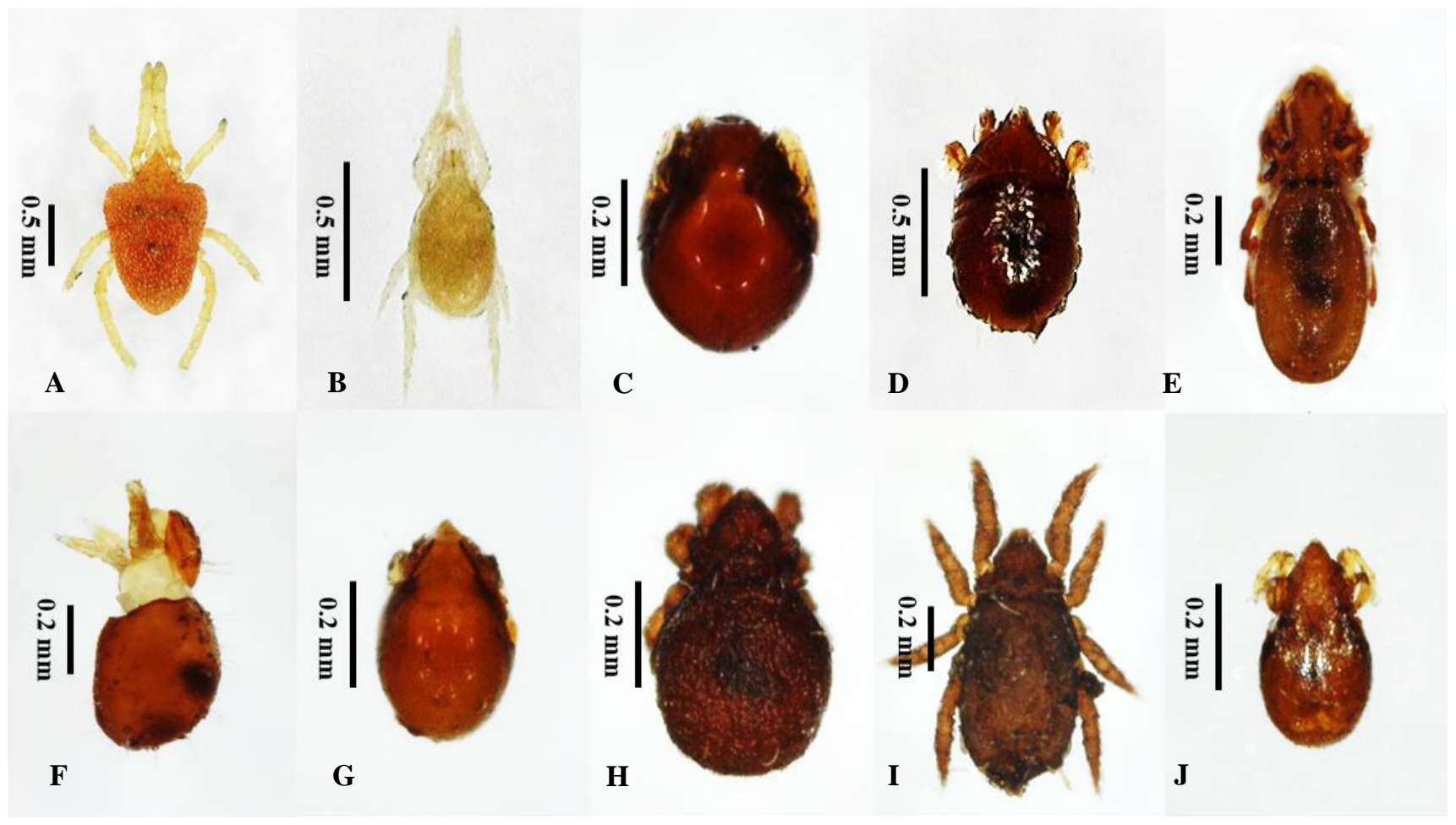

Figure 3. Edaphic mites found in this study; Prostigmata (A); Mesostigmata (B); and Oribatida (C-J) 
Table 2. The average number of individuals \pm SD of each mite family found in the five forest management systems, as well as the average of mite richness and the average number of total predaceous and detritivorous mites

\begin{tabular}{|c|c|c|c|c|c|c|c|c|}
\hline \multirow{2}{*}{ Family } & \multirow{2}{*}{ Guild } & \multicolumn{5}{|c|}{ Forest management systems } & \multirow{2}{*}{$F_{4,35}$} & \multirow{2}{*}{$\boldsymbol{P}$} \\
\hline & & SF & PF & PC & MC & MX & & \\
\hline \multicolumn{9}{|l|}{ Prostigmata } \\
\hline Trombidiidae & Pre & $0.62 \pm 1.4 \mathrm{a}$ & $0.37 \pm 0.51 \mathrm{a}$ & $0.25 \pm 0.70 \mathrm{a}$ & $0.00 \pm 0.00 \mathrm{a}$ & $0.50 \pm 0.53 \mathrm{a}$ & 1.00 & 0.417 \\
\hline \multicolumn{9}{|l|}{ Mesostigmata } \\
\hline Laelapidae & Pre & $37.38 \pm 25.38 \mathrm{ab}$ & $57.88 \pm 32.07 \mathrm{a}$ & $44.75 \pm 23.72 \mathrm{a}$ & $14.63 \pm 6.16 \mathrm{bc}$ & $8.12 \pm 6.37 \mathrm{c}$ & 12.19 & 0.000 \\
\hline \multicolumn{9}{|l|}{ Oribatida } \\
\hline Eremaeidae & Det & $11.38 \pm 10.68 \mathrm{ab}$ & $31.88 \pm 43.77 \mathrm{ab}$ & $68.50 \pm 75.53 \mathrm{a}$ & $7.12 \pm 8.37 \mathrm{ab}$ & $6.00 \pm 9.57 b$ & 3.61 & 0.014 \\
\hline Haplozetidae & Det & $9.12 \pm 17.53 \mathrm{a}$ & $4.87 \pm 5.35 \mathrm{a}$ & $19.38 \pm 39.46 \mathrm{a}$ & $12.13 \pm 29.90 \mathrm{a}$ & $1.25 \pm 2.76 \mathrm{a}$ & 1.02 & 0.406 \\
\hline Galumnidae & Det & $15.75 \pm 19.32 \mathrm{ab}$ & $38.00 \pm 29.85 \mathrm{a}$ & $29.50 \pm 23.87 \mathrm{a}$ & $2.00 \pm 3.50 \mathrm{~b}$ & $9.62 \pm 17.04 \mathrm{ab}$ & 6.15 & 0.000 \\
\hline Lohmanniidae & Det & $1.37 \pm 1.40 \mathrm{ab}$ & $4.62 \pm 5.29 \mathrm{a}$ & $2.75 \pm 1.98 \mathrm{a}$ & $0.50 \pm 0.75 a b$ & $0.12 \pm 0.35 b$ & 4.16 & 0.007 \\
\hline Otochepheidae & Det & $0.25 \pm 0.70 a$ & $1.62 \pm 2.72 \mathrm{a}$ & $0.87 \pm 1.35 \mathrm{a}$ & $0.62 \pm 1.40 \mathrm{a}$ & $0.25 \pm 0.70 a$ & 0.79 & 0.538 \\
\hline Mesoplophoridae & Det & $0.25 \pm 0.70 \mathrm{a}$ & $0.62 \pm 1.06 \mathrm{a}$ & $0.62 \pm 1.40 \mathrm{a}$ & $0.00 \pm 0.00 \mathrm{a}$ & $0.25 \pm 0.46 \mathrm{a}$ & 0.83 & 0.509 \\
\hline Oribatulidae & Det & $0.75 \pm 1.75 \mathrm{a}$ & $3.62 \pm 5.15 \mathrm{a}$ & $3.12 \pm 2.53 \mathrm{a}$ & $0.62 \pm 1.76 \mathrm{a}$ & $0.75 \pm 1.16 \mathrm{a}$ & 2.75 & 0.053 \\
\hline Suctobelbidae & Det & $0.12 \pm 0.35 \mathrm{a}$ & $1.75 \pm 3.24 \mathrm{a}$ & $0.37 \pm 0.74 \mathrm{a}$ & $0.25 \pm 0.70 \mathrm{a}$ & $0.25 \pm 0.46 a$ & 1.15 & 0.348 \\
\hline Crotonioidea $^{\dagger}$ & Det & $0.50 \pm 0.53 b$ & $3.00 \pm 2.33 \mathrm{ab}$ & $4.00 \pm 3.29 \mathrm{a}$ & $1.37 \pm 1.84 \mathrm{ab}$ & $0.75 \pm 1.75 b$ & 4.51 & 0.004 \\
\hline Brachypylina* & Det & $7.87 \pm 9.94 \mathrm{ab}$ & $22.50 \pm 20.66 \mathrm{a}$ & $13.00 \pm 9.63 \mathrm{ab}$ & $2.12 \pm 1.72 b$ & $3.12 \pm 4.67 \mathrm{~b}$ & 3.62 & 0.014 \\
\hline Richness & & $6.12 \pm 1.64 \mathrm{ab}$ & $8.12 \pm 1.64 \mathrm{a}$ & $8.37 \pm 1.92 \mathrm{a}$ & $5.37 \pm 1.68 \mathrm{ab}$ & $4.62 \pm 2.72 b$ & 4.30 & 0.006 \\
\hline Total predators & & $38.75 \pm 26.72 \mathrm{ab}$ & $61.88 \pm 34.24 \mathrm{a}$ & $43.38 \pm 24.32 \mathrm{a}$ & $15.50 \pm 6.56 b$ & $8.87 \pm 7.27 \mathrm{c}$ & 12.10 & 0.000 \\
\hline Total detritivores & & $48.63 \pm 45.17 \mathrm{ab}$ & $112.30 \pm 87.47 \mathrm{a}$ & $143.00 \pm 134.30 \mathrm{a}$ & $26.75 \pm 34.73 b$ & $24.38 \pm 25.98 b$ & 5.53 & 0.001 \\
\hline
\end{tabular}

Table 3. Community characteristics of edaphic mites found in the five forest management systems represented by diversity indices (means $\pm \mathrm{SD})$

\begin{tabular}{|c|c|c|c|c|c|c|c|c|}
\hline \multirow{2}{*}{ Edaphic mites } & \multirow{2}{*}{$\begin{array}{l}\text { Community } \\
\text { characteristics }\end{array}$} & \multicolumn{5}{|c|}{ Forest management systems } & \multirow{2}{*}{$F_{4,35}$} & \multirow{2}{*}{$\boldsymbol{P}$} \\
\hline & & SF & PF & $\mathbf{P C}$ & MC & MX & & \\
\hline \multirow[t]{3}{*}{ Total mites } & Biodiversity $\left(H^{\prime}\right)$ & $1.27 \pm 0.34 \mathrm{ab}$ & $1.52 \pm 0.21 \mathrm{ab}$ & $1.54 \pm 0.17 \mathrm{a}$ & $1.09 \pm 0.23 \mathrm{ab}$ & $1.07 \pm 0.52 b$ & 3.84 & 0.010 \\
\hline & Evenness $(E)$ & $0.44 \pm 0.12 \mathrm{ab}$ & $0.53 \pm 0.07 a b$ & $0.54 \pm 0.06 \mathrm{a}$ & $0.38 \pm 0.08 a b$ & $0.37 \pm 0.18 b$ & 3.85 & 0.010 \\
\hline & Dominance $(D)$ & $0.36 \pm 0.14 \mathrm{a}$ & $0.27 \pm 0.05 \mathrm{a}$ & $0.26 \pm 0.05 \mathrm{a}$ & $0.40 \pm 0.11 \mathrm{a}$ & $0.29 \pm 0.15 \mathrm{a}$ & 2.17 & 0.092 \\
\hline \multirow[t]{3}{*}{ Litter-dwelling mites } & Biodiversity $\left(H^{\prime}\right)$ & $1.08 \pm 0.50 \mathrm{ab}$ & $1.46 \pm 0.19 \mathrm{a}$ & $1.48 \pm 0.18 \mathrm{a}$ & $0.96 \pm 0.28 b$ & $0.87 \pm 0.47 b$ & 5.44 & 0.001 \\
\hline & Evenness $(E)$ & $0.38 \pm 0.17 \mathrm{ab}$ & $0.51 \pm 0.06 \mathrm{a}$ & $0.52 \pm 0.06 \mathrm{a}$ & $0.32 \pm 0.19 b$ & $0.30 \pm 0.16 b$ & 5.44 & 0.001 \\
\hline & Dominance $(D)$ & $0.43 \pm 0.21 \mathrm{a}$ & $0.28 \pm 0.06 \mathrm{a}$ & $0.28 \pm 0.06 \mathrm{a}$ & $0.47 \pm 0.15 a$ & $0.32 \pm 0.14 \mathrm{a}$ & 2.93 & 0.034 \\
\hline \multirow[t]{3}{*}{ Soil-dwelling mites } & Biodiversity $\left(H^{\prime}\right)$ & $1.01 \pm 0.33 \mathrm{a}$ & $1.00 \pm 0.48 \mathrm{a}$ & $1.34 \pm 0.26 \mathrm{a}$ & $0.87 \pm 0.55 \mathrm{a}$ & $0.92 \pm 0.57 \mathrm{a}$ & 1.23 & 0.312 \\
\hline & Evenness $(E)$ & $0.35 \pm 0.11 \mathrm{a}$ & $0.35 \pm 0.17 \mathrm{a}$ & $0.47 \pm 0.09 \mathrm{a}$ & $0.30 \pm 0.19 a$ & $0.32 \pm 0.20 \mathrm{a}$ & 1.23 & 0.312 \\
\hline & Dominance $(D)$ & $0.33 \pm 0.25 \mathrm{a}$ & $0.32 \pm 0.15 \mathrm{a}$ & $0.26 \pm 0.10 \mathrm{a}$ & $0.48 \pm 0.28 \mathrm{a}$ & $0.27 \pm 0.32 \mathrm{a}$ & 1.09 & 0.373 \\
\hline \multicolumn{9}{|c|}{$\begin{array}{l}\text { Note: Means followed by the same letters within each row are not significantly different at } P<0.05 \text { according to Tukey's test. SF i } \\
\text { secondary forest; PF is monoculture pine system; PC is pine + coffee system; MC is mahogany }+ \text { coffee system; and MX is mahogany }+ \\
\text { new cocoyam system }\end{array}$} \\
\hline \multicolumn{9}{|c|}{$\begin{array}{l}\text { Table 4. The relationship between environment physical parameters and the abundance, richness, and diversity of edaphic mites } \\
\text { according to Pearson's correlation. }\end{array}$} \\
\hline \multirow[t]{2}{*}{ Physical parameters } & \multicolumn{2}{|c|}{ Edaphic mite abundance } & \multicolumn{3}{|c|}{ Edaphic mite richness } & \multicolumn{3}{|c|}{ Edaphic mite diversity } \\
\hline & $r$ & $P$ & & $r$ & $P$ & $r$ & & $P$ \\
\hline Litter thickness & 0.982 & $0.002 *$ & & 984 & $0.002 *$ & 0.969 & & $06^{*}$ \\
\hline Litter temperature & 0.847 & 0.069 & & 805 & 0.099 & 0.869 & & 56 \\
\hline Litter relative humidity & -0.760 & 0.135 & & 716 & 0.172 & -0.799 & & 105 \\
\hline Litter $\mathrm{pH}$ & -0.541 & 0.345 & & 483 & 0.408 & -0.510 & & 380 \\
\hline Soil temperature & 0.664 & 0.221 & & 695 & 0.192 & 0.716 & & 173 \\
\hline Soil relative humidity & -0.701 & 0.186 & & 643 & 0.241 & -0.726 & & 165 \\
\hline Soil pH & -0.754 & 0.140 & & 734 & 0.157 & -0.798 & & 105 \\
\hline
\end{tabular}

Note: * denotes a significant relationship at $P<0.05$ 
Based on the correlation analysis, we found that only litter thickness had a significant impact on edaphic mites. Litter thickness has been known as one of the most influential factors affecting edaphic mite abundance, richness, and diversity (Gergócs et al. 2015; Kamczyc et al. 2018; Urbanowski et al. 2021). Litters are the primary food source and habitat for edaphic mites, in particular, oribatids. A litter from a given plant species may has different chemical composition or decomposition rate from other litters (Horodecki et al. 2018; Berg and McClaugherty 2020). The deeper litter layer observed in pine monoculture and pine + coffee systems could be due to a slower decomposition rate of pine needles than mahogany leaves. Urbanowski et al. (2018) revealed that the density of edaphic mites was significantly higher on a slow-degraded litter, such as oak (Quercus robur L.) leaves. They assumed that it might be associated with longer periods of habitation by soil fauna on a slowdegraded litter. In addition, Spaans et al. (2019) also observed variations in edaphic mite community characteristics between ash (Fraxinus excelsior L.) and sycamore (Acer pseudoplatanus L.) habitats because sycamore leaves decompose more slowly than ash leaves. Another aspect to take into account is the effects of litter on microclimate and microbial communities. Since most oribatids are also fungivores, the presence of fungi in the litter layer is important (Schneider and Maraun 2005; Ingimarsdóttir et al. 2012). Therefore, we assume that pine litter may be a more favorable habitat for edaphic mites due to its chemical composition (including the nutritional value), microclimates (related to the physical structure of pine litter), and microorganisms. Our results are in line with a previous investigation by Maribie et al. (2011). According to Maribie et al. (2011), the high abundance and diversity of edaphic mites in pine forests were caused by the higher litter inputs, indicating a rich food source and suitable habitat.

Our findings indicate that the abundance, richness, and diversity of edaphic mites on managed forests are comparable to secondary forests. However, we deduce that litter thickness and types are likely to affect the edaphic mite assemblages. Hence, selecting appropriate dominant tree species is crucial when secondary forests will be converted into production forests or agroforestry. For instance, the conversion of secondary forests to pine systems seems to be the right choice. The tree species selected should have a high litter input and high-quality litter in an attempt to preserve edaphic mite communities. Our study also illustrates that proper forest management systems can ensure the continuity of ecosystem services provided by soil fauna in addition to providing harvestable goods.

\section{ACKNOWLEDGEMENTS}

The authors would like to thank Novia Dwi Putri for her help during the collection of litter and soil samples. The laboratory assistance provided by Putri Dewi Sartika,
Herdhiana Rachmatika, and Reza Dias Fiki Refanda was greatly appreciated.

\section{REFERENCES}

Acharya S, Datta TK. 2019. Diversity of soil cryptostigmatid mites (Acari: Oribatida) of Himachal Pradesh, India, from an altitudinal perspective. J Asia-Pac Biodiv 12: 357-362. DOI: 10.1016/j.japb.2019.03.014.

Amani M, Khajehali J, Moradi-Faradonbeh M, Macchioni F. 2020. Species diversity of soil mites (Acari: Mesostigmata) under different agricultural land use types. Persian J Acarol 9(4): 353-366. DOI: 10.22073/pja.v9i4.59610.

Ardestani MM, Keshavarz-Jamshidian M, van Gestel CAM, van Straalen NM. 2020. Avoidance tests with the oribatid mite Oppia nitens (Acari: Oribatida) in cadmium-spiked natural soils. Exp Appl Acarol 82: 81-93. DOI: 10.1007/s10493-020-00536-9.

Badejo MA, Tian G. 1999. Abundance of soil mites under four agroforestry tree species with contrasting litter quality. Biol Fertil Soils 30: 107-112. DOI: 10.1007/s003740050595.

Balogh J, Balogh P. 1992. The Oribatid Mites Genera of the World. The Hungarian National Museum Press, Budapest.

Bedano JC, Cantú MP, Doucet ME. 2006. Influence of three different land management practices on soil mite (Arachnida: Acari) densities in relation to a natural soil. Appl Soil Ecol 32: 293-304. DOI: 10.1016/j.apsoil.2005.07.009.

Behan-Pelletier VM. 1999. Oribatid mite biodiversity in agroecosystems: role for bioindication. Agric Ecosyst Environ 74(1-3): 411-423. DOI: 10.1016/S0167-8809(99)00046-8.

Berg J, McClaugherty C. 2020. Plant Litter: Decomposition, Humus Formation, Carbon Sequestration. Springer, Cham. DOI: 10.1007/978-3-030-59631-6.

Bria D, Widyastuti R, Santoso S. 2019. Study of oribatids population on three types of land use at PT Nusantara VIII plantation, Cisarua subdistrict Bogor, West Java. J Degrade Min Land Manage 6(2): 16671673. DOI: $10.15243 / \mathrm{jdmlm} .2019 .062 .1667$.

Cao Z, han X, Hu C, Chen J, Zhang D, Steinberger Y. 2011. Changes in the abundance and structure of a soil mite (Acari) community under long-term organic and chemical fertilizer treatments. Appl Soil Ecol 49: 131-138. DOI: 10.1016/j.apsoil.2011.06.003.

de Groot GA, Jagers op Akkerhuis GAJM, Dimmers WJ, Charrier X, Faber JH. 2016. Biomass and diversity of soil mite functional groups respond to extensification of land management, potentially affecting soil ecosystem services. Front Environ Sci DOI: 10.3389/fenvs.2016.00015.

Dirilgen T, Arroyo J, Dimmers DJ, Faber J, Stone D, da Silva PM, Carvalho F, Schmelz R, Griffiths BS, Fransisco R, Creamer RE, Sousa JP, Bolger T. 2016. Mite community composition across a European transect and its relationships to variation in other components of soil biodiversity. Appl Soil Ecol 97: 86-97. DOI: 10.1016/j.apsoil.2015.06.008.

Erdmann G, Scheu S, Maraun M. 2012. Regional factors rather than forest type drive the community structure of soil living oribatid mites (Acari, Oribatida). Exp Appl Acarol 57: 157-169. DOI: 10.1007/s10493-012-9546-9.

Evans GO. 1992. Principles of Acarology. CABI, Cambridge.

Gao M, Zhang Z, Liu D, Wu D. 2014. Relative roles of spatial factors, environmental filtering and biotic interactions in fine-scale structuring of a soil mite community. Soil Biol Biochem 79: 68-77. DOI: 10.1016/j.soilbio.2014.09.003.

Gergócs V, Hufnagel L. 2011. Oribatid mites (Acari: Oribatida) in microcosms - a review. Appl Ecol Environ Res 9(4): 355-368. DOI: 10.15666/aeer/0904_355368.

Gergócs V, Rétháti G, Hufnagel L. 2015. Litter quality indirectly influences community composition, reproductive mode and trophic structure of oribatid mite communities: A microcosm experiment. Exp Appl Acarol 67: 335-356. DOI: 10.1007/s10493-015-9959-3.

González G, Seastedt TR. 2000. Comparison of the abundance and composition of litter fauna in tropical and subalpine forests. Pedobiologia 44(5): 545-555. DOI: 10.1078/S0031-4056(04)70070-0.

Khabir ZH, Irani-Nejhad KH, Moghaddam M, Khanjani M. 2015. Community structure of oribatid mites (Acari: Oribatida) in 
rangelands of West Azerbaijan Province, Iran. Int J Acarol 41(4): 344-355. DOI: 10.1080/01647954.2015.1033458.

Horodecki P, Jagodziński AM. 2017. Tree species effects on litter decomposition in pure stands on afforested post-mining sites. For Ecol Manag 406: 1-11. DOI: 10.1016/j.foreco.2017.09.059.

Horodecki P, Nowiński M, Jagodziński AM. 2018. Advantages of mixed tress stands in restoration of upper soil layers on postmining sites: A five-year litter decomposition experiment. Land Degrad Dev 30(1): 3 13. DOI: $10.1002 / \mathrm{ldr} .3194$

Huguier P, Manier N, Owojori OJ, Bauda P, Pandard P, Römbke J. 2015. The use of soil mites in ecotoxicology: a review. Ecotoxicology 24: 118. DOI: $10.1007 / \mathrm{s} 10646-014-1363-\mathrm{y}$.

Ingimarsdóttir M, Caruso T, Ripa J, Magnúsdóttir ÓB, Migliorini M, Hedlund K. 2012. Primary assembly of soil communities: disentangling the effect of dispersal and local environment. Oecologia 170: 745-754. DOI: 10.1007/s00442-012-2334-8.

Kamczyc J, Skorupski M, Dyderski MK, Gazda A, Hachułka M, Horodecki P, Kałucka I, Malicki M, Pielech R, Smoczyk M, Wierzcholska S, Jagodziński AM. 2018. Response of soil mites (Acari, Mesostigmata) to long-term Norway spruce plantation along a mountain stream. Exp Appl Acarol 76: 269-286. DOI: 10.1007/s10493-018-0314-3.

Klarner B, Maraun M, Scheu S. 2013. Trophic diversity and niche partitioning in a species rich predator guild - Natural variations in stable isotope ratios $\left({ }^{13} \mathrm{C} /{ }^{12} \mathrm{C},{ }^{15} \mathrm{~N} /{ }^{14} \mathrm{~N}\right.$ ) of mesostigmatid mites (Acari, Mesostigmata) from Central European beech forests. Soil Biol Biochem 57: 327-333. DOI: 10.106/j.soilbio.2012.08.013.

Krantz GW, Walter DE. 2009. A Manual of Acarology: Third Edition. Texas Tech University Press, Lubbock.

Lisafitri Y, Widyastuti R, Santosa DA. 2015. Population dynamics of oribatid mites in the oilpalm plantation area at Bajubang Batanghar Jambi. J Tanah Lingk 17(1): 33-38. DOI:10.29244/jitl.17.1.33-38. [Indonesian]

N'Dri JK, Seka FA, Pokou PK, N'Da RAG, Lagerlöf J. 2017. Abundance and diversity of soil mite (Acari) communities after conversion of tropical secondary forest into rubber plantations in Grand-Lahou, C ôte d'Ivoire. Ecol Res 32(6): 909-919. DOI: 10.1007/s11284-0171499-3.

Navarro-Campos C, Pekas A, Moraza ML, Aguilar A, Garcia-Marí F. 2012. Soil-dwelling predatory mites in citrus: their potential as natural enemies of thrips with special reference to Pezothrips kellyanus (Thysanoptera: Thripidae). Biol Control 63(2): 201-209. DOI: 10.1016/j.biocontrol.2012.07.007.Maribie CW, Nyamasyo GHN, Ndegwa PN, Mung'atu JK, Lagerlöf J, Gikungu M. 2011. Abundance and diversity of soil mites (Acari) along a gradient of land use types in Taita Taveta, Kenya. Trop Subtrop Agroecosyst 13: 11-26.

Meehan ML, Song Z, Lumley LM, Cobb TP, Proctor H. 2019. Soil mites as bioindicators of disturbance in the boreal forest in northern Alberta, Canada: Testing taxonomy sufficiency at multiple taxonomic levels. Ecol Indic 102: 349-365. DOI: 10.1016/j.ecolind.2019.02.043.

Minor MA, Cianciolo JM. 2007. Diversity of soil mites (Acari: Oribatida, Mesostigmata) along a gradient of land use types in New York. Appl Soil Ecol 35: 140-153. DOI: 10.1016/j.apsoil.2006.05.004.

Mori AS, Ota AT, Fuji S, Seino T, Kabeya D, Okamoto T, Ito MT, Kaneko N, Hasegawa M. 2015. Concordance and discordance between taxonomic and functional homogenization: responses of soil mite assemblages to forest conversion. Oecologia 179: 527-535. DOI: $10.1007 / \mathrm{s} 00442-015-3342-2$.

Murvanidze M, Mumladze L, Todria N, Salakaia M, Maraun M. 2019. Effect of ploughing and pesticides application on oribatid mite communities. Int J Acarol 45(4): 181-188. DOI: 10.1080/01647954.2019.1572222.

Oksanen J, Blanchet FG, Friendly M, Kindt R, Legendre P, McGlinn D, Minchin PR, O'hara RB, Simpson GL, Solymos P, Stevens MHH, Szoecs E, Wagner H. 2020. Package 'vegan': Community ecology package. Version 2.5-7. Available at https://cran.rproject.org/web/packages/vegan/vegan.pdf.
Park J, Mostafiz MM, Hwang HS, Jung DO, Lee KY. 2021. Comparison of the predation capacities of two soil-dwelling predatory mites, Gaeolaelaps aculeifer and Stratiolaelaps scimitus (Acari: Laelapidae), on three thrips species. J Asia-Pac Entomol 24(1): 397401. DOI: $10.1016 / \mathrm{j}$.aspen.2021.01.009.

Puspitarini RD, Fernando I, Rachmawati R, Hadi MS, Rizali A. 2021a. Host plant variability affects the development and reproduction of Tetranychus urticae. Int J Acarol DOI: 10.1080/01647954.2021.1915377.

Puspitarini RD, Fernando I, Widjayanti T, Ramadhatin A, Husna NL. 2021b. Physicochemical characteristics of stored products affect host preference and biology of Acarus siro (Acari: Acaridae). J Crop Prot 10(2): 281-293

R Core Team. 2020. R: A Language and Environment for Statistical Computing. R Foundation for Statistical Computing, Vienna.

Rueda-Ramírez D, Ramírez AV, Ravelo EE, de Moraes GJ. 2021. Edaphic mesostigmatid mites (Acari: Mesostigmata) and thrips (Insecta: Thysanoptera) in rose cultivation and secondary vegetation areas in the Bogotá plateau, Colombia. Int J Acarol 47(1): 8-22. DOI: 10.1080/01647954.2020.1866666.

Schneider K, Maraun M. 2005. Feeding preferences among dark pigmented fungal taxa ("Dematiacea") indicate limited trophic niche differentiation of oribatid mites (Oribatida, Acari). Pedobiologia 49(1): 61-67. DOI: 10.1016/j.pedobi.2004.07.010.

Seastedt TR. 1984. The role of microarthropods in decomposition and mineralization processes. Annu Rev Entomol 29: 25-46. DOI: 10.1146/annurev.en.29.010184.000325.

Smrž J. 2010. Nutritional biology of oribatid mites from different microhabitats in the forest. In: Sabelis M, Bruin J (eds). Trends in Acarology. Springer, Dordrecht. DOI: 10.1007/978-90-481-98375_34.

Spaans F, Caruso T, Hammer EC, Montgomery I. 2019. Trees in trimmed hedgerows but not tree health increase diversity of oribatid mite communities in intensively managed agricultural land. Soil Biol Biochem 138: 107568. DOI: 10.1016/j.soilbio.2019.107568.

Sulistyorini E, Widyastuti R, Santoso S. 2018. Diversity of oribatids (Acari) at different land use types in Mentebah, Kapuas Hulu, West Kalimantan. J Degrade Min Land Manage 5(4): 1355-1361. DOI: 10.15243/jdmlm.2018.054.1355.

Sylvain ZA, Buddle CM. 2010. Effects of forest stand type on oribatid mite (Acari: Oribatida) assemblages in a Southwestern Quebec forest. Pedobiologia 53: 321-325. DOI: 10.1016/J.PEDOBI.2010.03.001.

Urbanowski CK, Horodecki P, Kamczyc J, Skorupski M, Jagodziński AM. 2018. Succession of mite assemblages (Acari, Mesostigmata) during decomposition of tree leaves in forest stands growing on reclaimed post-mining spoil heap and adjacent forest habitats. Forests 9(11): 718. DOI: 10.3390/f9110718.

Urbanowski CK, Horodecki P, Kamczyc J, Skorupski M, Jagodziński AM. 2021. Does litter decomposition affect mite communities (Acari, Mesostigmata)? A five-year litterbag experiment with 14 tree species in mixed forest stands growing on a post-industrial area. Geoderma 391: 114963. DOI: 10.1016/j.geoderma.2021.114963.

Vacante V. 2016. The Handbook of Mites of Economic Plants: Identification, Bio-ecology and Control. CABI, Wallingford. DOI: 10.1079/9781845939946.0001.

Wickings K, Grandy AS. 2011. The oribatid mite Scheloribates moestus (Acari: Oribatida) alters litter chemistry and nutrient cycling during decomposition. Soil Biol Biochem 43(2): 351-358. DOI: 10.1016/j.soilbio.2010.10.023

Zaitsev AS, Ryabinin NA, Tarasov AI, Shakhab SV. 2020. Potential anthropogenic influence on oribatid mite communities in ancient to modern settlements of the Russian Far East. Int J Acarol 46(5): 322326. DOI: $10.1080 / 01647954.2020 .1801838$.

Zhang ZQ. 2003. Mites of Greenhouses: Identification, Biology and Control. CABI, Wallingford. DOI: 10.1079/9780851995908.0000. 